\title{
KOŚCIÓŁ KATOLICKI NA LITWIE NA PRZEŁOMIE XV I XVI W.
}

W interesującym nas okresie Kościół katolicki na Litwie był jeszcze młody i nieokrzepły. W r. 1487 upłynęło dopiero sto lat od chrztu Litwy-Auksztoty, a w latach 1513-1517 minęło sto lat od chrystianizacji Litwy dolnej, czyli Żmudzi. Nic więc dziwnego, że nowa wiara jeszcze nie wszędzie wyparła stare wierzenia i powoli docierała do wszystkich mieszkańców tych ziem. Chodzi oczywiście o ziemie etnograficznie litewskie, gdyż Wielkie Księstwo Litewskie, złączone unią z Polską, było wówczas państwem bardzo rozległym i miało olbrzymią przewagę prawosławnej ludności ruskiej. Przedmiotem naszego zainteresowania, bardzo zresztą pobieżnego, będą dwie diecezje: wileńska i żmudzka, w szeroko pojętym „przełomie wieków”, mniej więcej od połowy XV do połowy XVI w., kiedy to $z$ wielką siłą dojdzie do głosu reformacja.

Powstanie abu biskupstw było związane $\mathrm{z}$ chrystianizacją Litwy, a następnie Żmudzi. Diecezja wileńska, założona dokumentem fundacyjnym króla Władysława Jagiełły z r. 1387 i bullą papieską z r. 1388, obejmowała olbrzymie terytoria, nie tylko etnograficznie litewskie, ale i rozległe tereny ruskie oraz północną część Podlasia z przewagą ludności polskiej. Biskupstwo żmudzkie, ze stolicą w Miednikach, zwanych później Worniami, zostało założone w r. 1417 i było małe w porównaniu z poprzednim, gdyż zajmowało zaledwie około $23000 \mathrm{~km}^{2}$ powierzchni. Biskupi żmudzcy od czasów bpa Macieja z Topoli (1464-1470) najczęściej rezydowali w Olsiadach.

Kościół katolicki w państwie litewskim miał pozycję uprzywilejowaną i był popierany przez panujących, ale i prawosławie cieszyło się tolerancją religijną. Biskupi wileńscy i żmudzcy reprezentowali nie tylko interesy Kościoła, ale często również interesy możnowładców litewskich, interesy państwa, które było suwerenne, choć związane unią z Koroną. Litwini pilnie strzegli, by „koroniarze” respektowali ich prawa, czy to na arenie politycznej czy kościelnej. Tak np. w czasie pertraktacji związanych z unią wileńską z r. 1499 panowie litewscy skarżyli się na pomijanie praw wielkiego księcia litewskiego do obsadzania litewskich biskupstw. W tym czasie bowiem nie było unii personalnej, gdyż królem polskim był Jan Olbracht, a wielkim księciem litewskim jego brat Aleksander (1492-1501). 
Przywilej ziemski króla Kazimierza Jagiellończyka z r. 1447 mówił o powierzaniu godności kościelnych na Litwie tylko tubylcom. Panujący jednak, królowie i wielcy książęta litewscy, wprowadzali często do kapituły, mianowali plebanami, a nawet wynosili na stolice biskupie swoich ludzi, pochodzących z Korony.

Biskupami w tym okresie są już przeważnie Litwini. Widzimy wśród nich także przedstawicieli najbogatszych rodów litewskich: Radziwiłłów i Holszańskich. Wojciech Radziwiłł był w latach 1507-1519 biskupem wileńskim, a Mikołaj - żmudzkim (1515-1529). Natomiast Paweł Holszański był na stolicy wileńskiej w latach 1536-1555. Odnotować téz należy, że w latach 1519-1536 diecezją wileńską rządził syn króla Zygmunta Starego - bp Jan z Książąt Litewskich. Większość biskupów żmudzkich rekrutowała się z prałatów i kanoników wileńskiej kapituły, natomiast na stolicę wileńską często przechodzono z biskupstwa łuckiego (Jan Łosowicz, Wojciech Radziwiłł, Paweł Holszański). Na czasy bpa W. Radziwiłła przypada pojawienie się na Litwie nowej godności - biskupa sufragana. Pierwszym sufraganem wileńskim, mniej więcej od r. 1512, był Jakub z Miechowa, natomiast $\mathrm{w}$ diecezji żmudzkiej sufragani datują się od pierwszej połowy XVII w.

$\mathrm{Na}$ pierwszą połowę XVI w. przypadają też pierwsze synody diecezjalne, ale tylko $\mathrm{w}$ diecezji wileńskiej. Pierwszy synod miał miejsce $w$ końcu 1520 lub na początku 1521 r. za bpa Jana z Książąt Litewskich. W pierwszej połowie XVI w. odbyło się ich W Wilnie pięć (1520/21, $1527 / 28,1538,1542,1546)$. Usiłowały one zaradzić bolączkom życia kościelnego $\mathrm{w}$ diecezji, wprowadzić więcej porządku $\mathrm{w}$ działalność duszpasterską i przypominały o obowiązkach duchownych. W diecezji żmudzkiej pierwszy synod odbył się już na początku drugiej połowy XVI wie$\mathrm{ku}$ - w r. 1555.

W interesujący nas okres diecezje litewskie wchodzą $\mathrm{z}$ bardzo rzadką siecią parafialną: $w$ diecezji wileńskiej było ich w r. 1450 zaledwie około 60, a w żmudzkiej - według obliczeń Jurgisa Gimbutasa - tylko 17 parafii. Ta ostatnia liczba jest chyba za wysoka, gdyż autor bierze tu pod uwagę fundacje kościołów, a nie aktualne ich istnienie. Kościoły parafialne mieściły się przede wszystkim na terenach zamieszkanych przez Litwinów na Wileńszczyźnie i bezpośrednio do niej przylegającej od południa i wschodu Rusi oraz w centralnej części Żmudzi. W poprzednim okresie główną rolę w zakładaniu parafii odgrywali królowie i wielcy książęta. Później rola ta przypadła bojarstwu. Wiązało się to z rozwojem posiadłości szlachty, przechodzeniem w jej ręce dóbr wielkoksiążęcych oraz $\mathrm{z}$ coraz bardziej intensywnym osadnictwem na terenach bardzo słabo zaludnionych lub spustoszonych w czasie wojen. Takimi pustoszami były zwłaszcza ziemie leżące między Niemnem i Prusami 
oraz zachodnia i północna Żmudź. Ilość parafii zaczęła się dość szybko powiększać. W końcu XV w. biskupstwo wileńskie liczyło już 130 kościołów parafialnych, a żmudzkie - według Zenona Ivinskisa - tylko 18 (J. Gimbutas podaje 24).

Pierwsza połowa XVI w. to dalszy i szybki rozwój sieci parafialnej. $\mathrm{W}$ diecezji wileńskiej przybywa $\mathrm{w}$ tym czasie około 130 parafii, tak że w r. 1553 - według rejestrów poborowych - osiąga liczbę 259. Biskupstwo żmudzkie powiększa swój stan o około 20 nowych parafii i razem ich liczba wynosi 43. Jest rzeczą charakterystyczną, że najgęstsza sieć parafialna była na ziemiach etnograficznie litewskich i na terenach ruskich, przylegających do litewskich obszarów od południa i południowego wschodu. Biorąc pod uwagę późniejszy podział na powiaty (1566), w powiatach litewskich diecezji wileńskiej (wileńskim, lidzkim, oszmiańskim, trockim i wiłkomierskim) były aż 144 parafie, w 4 powiatach ruskich: grodzieńskim, mińskim, nowogródzkim i wołkowyskim - 70 parafii, a na resztę terytorium biskupstwa przypadało zaledwie 45 ośrodków parafialnych. Parafie powstawały więc tam, gdzie mieszkała ludność litewska, bądź w zwartej masie, bądź też wśród ludności ruskiej. Ta ludność katolicka wśród Rusinów - to była przede wszystkim szlachta, choć były też i skupiska chłopskiej ludności litewskiej wśród Rusinów. Przypuszcza się, że katolickie ośrodki duszpasterskie spełniały również pewną rolę narodową - zachowywały odrębność Litwinów od Rusinów.

Rozwijająca się $\mathrm{w}$ obu diecezjach sieć parafialna przez długi czas nie była organizowana $\mathrm{w}$ dekanaty. $\mathrm{Z}$ diecezji żmudzkiej tego okresu nie mamy żadnych śladów organizacji dekanalnej. Dopiero za czasów bpa Stanisława Kiszki w pierwszej połowie XVII w. biskupstwo żmudzkie było podzielone na 4 dekanaty. $\mathrm{W}$ diecezji wileńskiej natomiast początki dekanatów sięgają połowy XVI w. Z synodu wileńskiego z r. 1555 wiadomo, że był już podział na dekanaty, skoro zalecono, aby w każdym był oficjał wiejski. W rejestrze podatkowym z r. 1553 kościoły parafialne spisane są według podziału na 5 ,kluczy”: trocki, mojszagolski, antokolski, miednicki i rudomiński. Podobny podział na 5 części, „którymi kierują decani rurales", podaje jeszcze bp Benedykt Wojna w swojej relacji do Rzymu z r. 1605. Występują tu następujące dekanaty: wileński, niemenczyński, rudnicki, miednicki i rudomiński. Stąd można wnioskować, że ruskie słowo „klucz” jest odpowiednikiem terminu „dekanat”. Dziwny był ten podział, gdyż wszystkie ośrodki dekanalne skupiały się w pobliżu stolicy diecezji.

Powstaje z kolei pytanie o klasztory. Jakie zakony miały tu już swoje domy i jaki mógł być udział zakonników w życiu diecezji? Najbardziej czynnym zakonem na Litwie, zwłaszcza w pierwszym okresie, byli fran- 
ciszkanie. W r. 1500 mieli oni 4 klasztory: dwa w Wilnie, w Kownie i Oszmianie. Pomijam tu domy w Pińsku i Drohiczynie, jako leżące na Polesiu i południowym Podlasiu, należące do diecezji łuckiej. Również bernardyni w końcu XV w. mieli 4 klasztory: w Wilnie, Kownie, Tykocinie i Połocku. Ponadto w tym okresie były jeszcze domy kanoników regularnych od pokuty (Bystrzyca i Miedniki), augustianów (Grodno) i benedyktynów (Troki). Razem było więc zaledwie 15 klasztorów. Jest rzeczą bardzo ciekawą, że w pierwszej połowie XVI w. nie widać ożywienia w zakładaniu nowych placówek zakonnych na Litwie. Powstają jedynie trzy klasztory: dominikanów w Wilnie (1501), bernardynów w Budsławiu (1504) i karmelitów dawnej obserwacji w Wilnie przy kościele św. Jerzego (1509). Daje to razem w połowie XVI w. tylko 15 domów zakonnych. Dziwić może fakt, że w diecezji żmudzkiej do tego czasu nie założono ani jednego klasztoru. Zakony żeńskie reprezentował zaledwie jeden klasztor - bernardynek w Wilnie na Zarzeczu, założony w r. 1494 .

Sieć placówek zakonnych na Litwie była więc bardzo rzadka i trudno chyba mówić o większym oddziaływaniu zakonników na ludność, zwłaszcza poza ośrodkami miejskimi. Najbardziej czynne były najliczniejsze zakony - franciszkanie i bermardyni. Bernardyni litewscy jednak w pierwszej połowie XVI w. prowadzili walkę o własną prowincję, którą otrzymali w r. 1530. Te walki i zmniejszanie się przez nie liczby bernardynów ograniczyły do minimum ich oddziaływanie duszpasterskie.

Przejdźmy teraz do zagadnień dotyczących wewnętrznego życia Kościoła litewskiego, duszpasterzy, ich pracy, religijności wiernych, w jakim stopniu została już schrystianizowana ludność i jej życie społeczne. Sa to sprawy trudne do uchwycenia na podstawie dostępnych źródeł i istniejących opracowań. Trzeba powiedzieć, że wkrótce po chrzcie Litwy Kościół, przede wszystkim w osobach biskupów, włączył się w życie polityczne i społeczne. Schrystianizowano uroczystości o charakterze państwowym. Wspomnieć tu trzeba zwłaszcza obrzęd obejmowania władzy przez wielkich książąt litewskich, zwany , podniesieniem" na tron wielkoksiążęcy. W interesującym nas okresie miał on miejsce trzykrotnie: $w \mathrm{r}$. 1492 biskup wileński Wojciech Tabor w katedrze wileńskiej „podniósł” księcia Aleksandra, w 1506 ten sam biskup - Zygmunta Starego, a w 1529 - biskup Jan z Książąt Litewskich dokonał tego ceremoniału z małoletnim wówczas Zygmuntem Augustem.

Biskupi byli też obecni przy podejmowaniu najważniejszych decyzji państwowych, uczestniczyli w naradach, ich podpisy znajdujemy na wydawanych przez panujących ważnych dokumentach. Przyjmowali również pod swoją opiekę w katedrze wileńskiej doczesne szczątki panujących. W r. 1484 został tam pochowany syn króla Kazimierza Jagiellończyka 
św. Kazimierz, a w 1506 - król i wielki ksłiażę litewski Aleksander. Potem spoczęły tu jeszcze dwie królowe - Elżbieta i Barbara, żony Zygmunta Augusta ${ }^{1}$. Duchowieństwo coraz bardziej przenikało w życie społeczne, ale przede wszystkim wyższych warstw. Te bowiem najszybciej zostały schrystianizowane. Duchowni byli nie tylko szerzycielami nowej wiary, ale również kultury, oświaty. Warto tu przytoczyć humorystycznie dziś brzmiący sposób leczenia, podany przez M. Stryjkowskiego. Mówiąc o ostatniej chorobie króla Kazimierza Jagiellończyka w Grodnie, podaje, że gdy „doktorowie uleczyć nie mogli, bernardyni go leczyli grubym chlebem i pieczonymi gruszkami" 2. Otóż duchowieństwo, zarówno świeckie jak i zakonne, ma duże zasługi $w$ zorganizowaniu na Litwie lecznictwa, pomocy chorym i cierpiącym oraz $\mathrm{w}$ działalności charytatywnej. Pierwszy szpital w Wilnie został założony przez kanonika Marcina z Dusznik w r. 1518. Nie trzeba chyba mówić o zasługach Kościoła w zakresie szkolnictwa.

Biskupi troszczyli się o należytą obsadę parafii w swoich diecezjach, ale przede wszystkim przez proboszczów. Ci zaś na własną rękę szukali sobie wikariuszy bądź tych kapłanów, na których barki składali całą pracę duszpasterską, gdy sami posiadali jeszcze inne beneficja. W tym okresie na parafiach mamy nie tylko duchownych z Litwy, lecz także i z Korony. Wśród wikariuszy z Polski najczęściej występowali kapłani z diecezji płockiej, którzy na Litwie szukali sobie pracy. Parafie fundacji wielkoksiążęcej obsadzał swoimi ludźmi panujący. Nie zawsze było to szczęśliwe dla Kościoła. Na tym tle w r. 1501 w Mielniku biskup wileński W. Tabor uzyskał od króla Aleksandra prawo patronatu i obsadzania proboszczów 28 kościołów kolacji królewskiej, ale tylko dla siebie. Natomiast biskup żmudzki Marcin Linfari miał uzyskać w r. 1503 przywilej dalej idący, gdyż zezwalający biskupowi i jego następcom prawo obsadzania wszystkich parafii fundacji hospodarskiej. Bp Maciej Wołonczewski w swoim „Biskupstwie żmudzkim” łączy to z tym, że w r. 1502 na jedną $\mathrm{z}$ parafii żmudzkich został mianowany przez króla ks. Jan, Polak, który z Krakowa przybył do Worń do biskupa żmudzkiego i okazało się, że wcale nie umie on po litewsku. Biskup prosił więc króla, by takich księży więcej mu nie przysyłał, a w konsekwencji król wydał wspomniany dokument. Ks. Jan Fijałek podważył taką interpretację przyczyn tego przywileju, a nawet i jego zakres. Pozostaje jednak faktem, że biskupi starali się o to, by sami mogli obsadzać parafie stosownymi kapłanami. Troszczyli się także o to, by w parafiach litewskich pracowali kapłani znający język ludu. Ta troska zresztą przebija i z doku-

1 Wcześniej zostal pochowany w katedrze wileńskiej wielki książę Witold.

2 M. Stryjk owski, O poczatkach, wywodach, dzielnośiach, sprawach rycerskich $i$ domowych stawnego narodu litewskiego, żemojdzkiego $i$ ruskiego [...], Warszawa 1978, s. 539. 
mentów fundacyjnych parafii, w których fundatorzy zastrzegają, by kościoły miały kapłanów znających język miejscowej ludności. Z pewnością bywali księża nie znający języka swoich wiernych, ale raczej były to wypadki sporadyczne i są przekazy mówiące o tym, że starali się oni nauczyć języka litewskiego, by móc należycie pracować wśród swoich parafian. Można z pewnością przyjąć za ks. Fijałkiem, że „tępienia lub choćby przynajmniej ucisku mowy ludu litewskiego nie było nigdy. Bierna, czasowa i partykularna nieznajomość języka, a czynne stałe i powszechne jego prześladowanie lub ciemiężenie - to są dwie zupełnie różne sprawy" "

Praca duszpasterska w tym okresie z pewnością nie była łatwa. Chrześcijaństwo było jeszcze świeże, a parafie bardzo rozległe. W połowie XVI w. średnia powierzchnia parafii w diecezji żmudzkiej wynosiło do $600 \mathrm{~km}^{2}$, natomiast $\mathrm{w}$ powiatach litewskich diecezji wileńskiej wynosiła około $350 \mathrm{~km}^{2}$, a w powiatach ruskich — około $950 \mathrm{~km}^{2}$. Najwcześniej i najszybciej schrystianizowane zostały warstwy wyższe i ludność większych ośrodków. Warstwy wyższe były zresztą zainteresowane przyjęciem nowej wiary, gdyż to dawało im także korzyści doczesne i znaczenie w państwie. Natomiast ludność wiejska, zwłaszcza rozrzucona po lasach, mieszkająca daleko od ośrodków parafialnych, trwała długo w pogaństwie bądź też na nowego Boga patrzyła jeszcze przez pryzmat swoich dawnych wierzeń. Przykładem tego może być anegdotyczna opowieść Stryjkowskiego, odnosząca się prawdopodobnie do początków panowania Zygmunta Augusta: „Się to niedawno za naszego wieku i w Kownie trafiło, iż gdy na Wielki Piątek bernardyński kaznodzieja według zwyczaju o Męce Pańskiej każąc, znak umęczenia Pana Chrystusowego, gdy przyszło ad flagellationem, miotełką i biczem siekł. Żmodzin, chłop prosty, pytał towarzysza: A ka tataj muschi Kunigas? (Kogo bije ksiądz). On mu odpowiedział: Pana Diewa (Pana Boga). A on zapytał: Ar ana kuris mumus padare piktus rugius? (Czy tego, przez którego mamy nieurodzaj?) — bo się było tego roku zboże źle zrodziło. Anu (tego); a chłop zaraz krzyknął na kaznodzieję: Gieraj milas Kunige plak schita Diewa, piktus mumus dawe rugius! (Dobrze, miły księże, bij tego Boga, złe żyto nam bowiem dał!)" ${ }^{4}$. Stryjkowski był, jak wiemy, kanonikiem żmudzkim i proboszczem parafii Jurborg.

W przekazach historycznych mamy szereg informacji mówiących o panującym jeszcze na Litwie i Żmudzi bałwochwalstwie i o ludziach nie ochrzczonych. Bp M. Wołonczewski napisał o biskupie Macieju ze Żmudzi, rządzącym diecezją w latach 1483-1492, że „przez rozesłanych

3 J. Fijałek, Kościót Rzymsko-katolicki na Litwie, [w:] Polska i Litwa w dziejowym stosunku, Warszawa 1914, s. 332.

${ }_{4}^{4}$ M. Stry jkowski, Kronika polska, litewska, żmudzka i wszystkiej Rusi, Warszawa 1846 , s. 150 . 
księży wiele ludzi ochrzcił". Bp W. Tabor w diecezji wileńskiej na przełomie XV/XVI w. nad rzeką Niewiażą spotkał jeszcze resztki pogaństwa i, aby je zlikwidować, zbudował tam kościół. W latach dwudziestych XVI w. bp Jan z Książąt Litewskich, „zwiedzając szawelska włość, której wówczas był władcą, znalazł na pograniczu kurlandzkim wielu jeszcze mieszkańców w bałwochwalstwie, o prawdziwym Bogu wcale nie wiedzących" ${ }^{5}$. W r. 1547 Zygmunt August po czterech latach pobytu na Litwie pisał do biskupa krakowskiego Samuela Maciejowskiego: „Swieże jeszcze bardzo w tym naszym Wielkim Księstwie są powiewy wiary chrześcijańskiej. Tu bowiem, poza Wilnem, a szczególnie na Żmudzi, ciemny, nieokrzesany lud oddaje cześć boską (że zamilczę już o innych zabobonach) gajom, dębom, lipom, ruczajom, głazom, wężom wreszcie i składa im publiczne, a także prywatne ofiary" ".

W r. 1970 w czasie prac melioracyjnych na Żmudzi w miejscowości Szilales, na wysepce pośród bagien odkryto dobrze zachowane miejsce kultu pogańskiego - ołtarz ofiarny, którym był duży kamień z zagłębieniem, stojący na ponad metrowej wysokości fundamencie. Obok był drugi. Badacze uważają, że to miejsce kultu pogańskiego zostało zlikwidowane dopiero w XVII w. za sprawą jezuitów. Archeologowie odkryli ponadto jeszcze w innych miejscach Żmudzi i Auksztoty głazy, które ich zdaniem służyły do kultu pogańskiego po oficjalnym chrzcie Litwy i Żmudzi.

Przykłady te świadczą o tym, że przez długi jeszcze czas ludność „zapadłych miejscowości" oddawała się bałwochwalstwu i zabobonom. Duchowni zreszta $\mathrm{w}$ bardzo rozległych parafiach nie mogli sprostać wszystkim swoim zadaniom. Ludność sama $\mathrm{z}$ pewnością nie garnęła się do kapłanów po posługi sakramentalne. Wspomniany już Marcin ze Żmudzi pod koniec XV w. rozsyłał księży, aby chrzcili ludzi. Najprawdopodobniej chodziło tam o chrzest ludzi żyjących jeszcze w pogaństwie. W praktyce duchownych diecezji żmudzkiej z drugiej połowy XVI w. mamy, że tak określę „duszpasterstwo objazdowe". Wspomina o tym w swojej wizytacji z r. 1579 Tarquinius Peculus. Tym bardziej chyba musiało ono być wcześniej. W rozległych parafiach praktykowano objazdy raz do roku, a może i częściej, w czasie których chrzczono dzieci, a także błogosławiono związki małżeńskie. Sprawowano wówczas z pewnością i inne sakramenty.

Ciekawą rzeczą do zbadania pozostaje sprawa małżeństw kościelnych wśród Litwinów, jak szybko one się przyjęły, czy zostały zaakceptowane, czy też ludność przez dłuższy czas trzymała się dawnej praktyki. Wiadomo, że Litwini w czasach pogańskich uznawali jednożeństwo. Można jednak przypuścić, że nie szybko małżeństwo kościelne, zwłaszcza wśród ludu,

5 M. W ołonczewski, Biskupstwo żmujdzkie, Kraków 1898, s. 37-38.

${ }^{6}$ Cyt. za M. Kosmane m: Pogaństwo, chrześcijaństwo i synkretyzm na Litwie $w$ dobie przedreformacyjnej, „Komunikaty Mazursko-Warmińskie” 1 (1972) s. 133.

4 - Analecta Cracoviensia 
stało się powszechne. Trzeba tu wziąść pod uwagę praktykę prawosławnych Rusinów, u których przez długi czas utrzymywało się tzw. małżenstwo niewieńczone, czyli tylko na podstawie obopólnej umowy, a bez ślubu cerkiewnego. Być może na tych terenach, gdzie Litwini byli zmieszani z Rusinami, przyjęli od nich również praktykę małżeństwa niewieńczonego i trzeba było długiego okresu czasu, aby wprowadzić wymogi prawa kościelnego.

Wspomnieć trzeba również o praktyce pogrzebowej. U ludów bałtyckich dużą rolę w życiu społecznym odgrywał kult przodków. Jak więc wyglądało przyjęcie chrześcijańskich wymogów w tym względzie? Chrześcijaństwo przecież podtrzymywało wiare w życie pozagrobowe, ale nadawało jej nową treść. Istniała więc ogólnie mówiąc, ciągłość w poglądach na życie pozagrobowe. Podstawowym miejscem grzebania zmarłych były $w$ dalszym ciągu dawne cmentarze, $w$ jakimś tylko stopniu nowe, przy kościołach. Z badań starych ementarzy litewskich wynika, że na przełomie XIV/XV w. stosowano palenie ciał, a gdy zrezygnowano z pa-lenia, zdarzały się wypadki składania razem w grobie i konia. Wydaje się, że nowy sposób grzebania ciał w trumnach, znalazł dość szybko przyjęcie. Jeszcze $\mathrm{w} X V \mathrm{w}$. bardzo często wyposażano groby $\mathrm{w}$ przedmioty mające służyć zmarłym w ich przyszłym życiu. Najprawdopodobniej wyrażał się w tym swoisty synkretyzm $w$ poglądach na życie pozagrobowe, próba łączenia starych, pogańskich wierzeń z nowymi, chrześcijańskimi. Cmentarze grzebalne wioskowe, oprócz cmentarzy w miejscowości kościelnej, pozostały na Litwie do dziś i w obecnych czasach grzebie się na nich umarłych. Tak np. w parafii Mejszagoła koło Wilna obecnie jest około 8 czynnych cmentarzy wiejskich. Pozostały one z pewnością ze względów praktycznych, z powodu wielkich odległości od kościoła i małej liczby duchowieństwa.

Interesującym problemem jest współżycie katolików na Litwie $\mathrm{z}$ prawosławnymi Rusinami. Katolicy stykali się $\mathrm{z}$ prawosławnymi nie tylko na pograniczu litewsko-ruskim, lecz także i w samej Litwie. W Wilnie przed połową XVI w. było 14 kościołów i 15 cerkwi. Cerkwie byly też w Trokach i jeszcze dalej - w Poporciach. Współżycie wyznawców obu obrządków nie zawsze układało się dobrze. Tak np. w czasach bpa Jana z Książąt Litewskich - jak podaje ks. J. Kurczewski - Rusini w Wilnie ,oplwali i srođze pobili dwóch kapłanów katedralnych, spokojnie idących na Zarzecz" ${ }^{7}$. Rzeczą bardzo ciekawą byłoby prześledzenie, jak układały się stosunki katolicko-prawosławne na styku, na pograniczu. oraz tam gazie byli przemieszani.

W Wilnie, jednym z największych miast Rzeczypospolitej, o bardzo zróżnicowanej narodowościowo i wyznaniowo ludności, można by sprawy

\footnotetext{
7 J. Ku r c zew ski, Biskupstwo wileńskie, Wilno 1912, s. 34.
} 
współżycia przynajmniej w jakimś stopniu prześledzić na podstawie działalności cechów. Istniały one tu od XV w. Według Kazimierza Chodynickiego cechy były $w$ zasadzie instytucjami katolickimi, chociaż należeli do nich również wyznawcy innych obrządków chrześcijańskich. Wszyscy członkowie cechu musieli uczestniczyć w uroczystościach Kościoła katolickiego. To wskazuje, że katolicy mieli uprzywilejowane stanowisko, co z pewnością musiało rodzić niezadowolenia.

Do zagadnienia stosunków katolicko-prawosławnych należy zaliczyć sprawę przechodzenia Rusinów z prawosławia na katolicyzm i akcję duchowieństwa katolickiego $\mathrm{w}$ tym względzie. W tej kwestii pod koniec XV i na początku XVI w. były na Litwie rozbieżności między duchowieństwem świeckim i bernardynami. Bernardyni, w przeciwieństwie do księży diecezjalnych, stali na stanowisku, że chrzest prawosławnych jest ważny i przyjmując Rusinów na łono Kościoła katolickiego nie trzeba ich powtórnie chrzcić. Spór ten został rozstrzygnięty przez Stolicę Apostolską. W r. 1502 kanonik wileński Erazm Ciołek przywiózł z Rzymu decyzje papieskie, stojące na stanowisku ważności chrztu prawosławnych. Biskupi litewscy otrzymali wówczas polecenie przyjmowania Rusinów do Kościoła katolickiego bez powtórnego chrztu. Interesującą rzeczą jest, jak liczne były w tym okresie te konwersje.

W pobożności mieszkańców Wilna oraz panów litewskich pewną rolę na przełomie interesujących nas wieków zaczął odgrywać kult zmarłego w r. 1484 w Grodnie, a pochowanego w katedrze wileńskiej, królewicza Kazimierza. Kult jego zaczął się wśród wilnian wkrótce po śmierci, rycerstwo zaś spopularyzowało go w początkach XVI w. po wyprawie połockiej (1518), kiedy to zwycięstwo nad wojskiem moskiewskim łączono z postacią zmarłego $\mathrm{W}$ opinii świętości królewicza. Kaplica grobowa św. Kazimierza stała się szczególnie droga Litwinom. „Było to - jak napisał ks. Fijałek - pierwsze historyczne miejsce święte w Wilnie i na Litwie, droższe niż wszystkie inne relikwie przywożone tłumnie z Rzymu i wcześnie obdarzone odpustami papieskimi" ${ }^{8}$. Zaczynał się kult pierwszego własnego świętego.

Pod koniec lat dwudziestych XVI w. docierają na Litwę szermierze haseł reformacyjnych. W związku $\mathrm{z}$ tym bp Jan $\mathrm{z}$ Książąt Litewskich otrzymał od króla w r. 1530 upoważnienie do ścigania luteran i anabaptystów, a w r. 1542 bp Paweł Holszański uzyskał pomoc władzy świeckiej w ściganiu Abrahama Kulwiecia i jego towarzyszy. W pierwszej połowie XVI w. ruch reformacyjny jest jeszcze nieśmiały. Do tego czasu na Litwie powstał tylko jeden zbór luterański - w Żejmach Tyzenhauzów na Żmudzi, natomiast pierwszy zbór kalwiński otwarł w r. 1553

${ }^{8} \mathrm{~J} . \quad \mathrm{Fijalek}$, Opisy Wilna aż do połowy wieku XVII-go, „Ateneum Wileńskie" 2 (1924) nr 5-6 s. 131. 
w Brześciu Mikołaj Radziwiłł Czarny, ale poza Litwą właściwą. Dopiero wtedy, a więc od początku drugiej połowy XVI w. zaczęło się ciężkie zmaganie $\mathrm{z}$ reformacją. Wiemy, że Kościół katolicki $\mathrm{z}$ tej walki wyszedł zwycięsko. Jaka była zasługa nowych sił w służbie Kościoła, a jaka dotychczasowej akcji chrystianizacyjnej - pozostawiam jako pytanie. Kościół bowiem na Litwie-Auksztocie w chwili rozpoczynania się tej wielkiej próby miał zaledwie około 160 lat, a na Żmudzi był jeszcze o ćwierć wieku młodszy. Miał więc jakby prawo w konkretnych warunkach tego kraju być jeszcze nie ugruntowany.

Szczegółowe omówienie różnych zagadnień poruszonych w powyższym artykule znajdzie czytelnik $\mathrm{w}$ następujących publikacjach:

J. Barda ch, Studia $z$ ustroju i prawa Wielkiego Księstwa Litewskiego XV-XVII $w$., Warszawa 1970.

K. Chodynicki, Stosunki wyznaniowe w cechach wileńskich od XVI do XVIII w., [w:] Księga pamiattkowa ku czci Oswalda Balzera, t. 1, Lwów 1925, s. 117-131.

J. Fijałek, Kościót Rzymsko-Katolicki na Litwie, [w:] Polska i Litwa $w$ dziejowym stosunku, Warszawa-Kraków 1914, s. 37-333.

- Opisy Wilna a $\dot{z}$ do połowy wieku XV-go, „Ateneum Wileńskie" 1 (1923) s. $313-336,506-526 ; 2$ (1924) s. $122-158$.

- Pierwszy biskup sufragan wileński, którego nie było, „Kwartalnik Teologiczny Wileński" $1-2(1923 / 24)$ s. 515-521.

- Pierwszy synod diecezji wileńskiej w katedrze św. Stanisiawa, tamże, s. $81-88$.

V. Gidžiunas, De fratribus minoribus in Lituania, Romae 1950.

- De initiis fratrum minorum de observantia in Lituania, „Archivum Franciscanum Historicum" 63 (1970) s. 44-103.

- Vienuolijos Lietuvoje XIII_XX amžiuje, „Metraštis” 5 (1970) s. $261-296$.

J. Gimbutas, Lietuvos bažnyčiu chronologia ir statistika, "Metraštis” 5 (1970) s. $215-260$.

K. K a n t a k, Bernardyni polscy, Lwów 1933.

- Franciszkanie polscy, Kraków 1937-1938.

M. Kosman, Drogi zaniku pogaństwa u Bałtów, Wrocław 1976.

- Konflikty wyznaniowe w Wilnie (schyłek XV-XVII w.), „Kwartalnik Historyczny" 79 (1972) s. 3-23. 
- Pogaństwo, chrześcijaństwo i synkretyzm na Litwie $w$ dobie przedreformacyjnej, „Komunikaty Mazursko-Warmińskie” 16 (1972) s. $103-137$.

- Tolerancja wyznaniowa na Litwie do XVIII wieku, „Odrodzenie i Reformacja w Polsce" 18 (1973) s. 95-123.

- Reformacja i kontrreformacja w Wielkim Księstwie Litewskim $w$ świetle propagandy wyznaniowej, Wrocław 1973.

T. Krahel, Historiografia (archidiecezji wileńskiej do 1939 roku, [w:] Studia $z$ historii Kościoła $w$ Polsce, t. 5, Warszawa 1979, s. 1179.

B. Kumor, Granice metropolii i diecezji polskich (968-1939), „Archiwa, Biblioteki i Muzea Kościelne" 19 (1969) s. 292-295.

J. Ku r c z e w ski, Biskupstwo wileńskie, Wilno 1912.

- Kościół zamkowy czyli katedra wileńska w jej dziejowym, liturgicznym, architektonicznym $i$ ekonomicznym rozwoju, Wilno 1916-1918.

H. Ło w mi án ki, Wielkie Księstwo Litewskie - zagadnienia ustrojowe i prawne, „Kwartalnik Historyczny” 79 (1972) s. 885-896.

J. O c hm ań $\mathrm{ski}$, Biskupstwo wileńskie w średniowieczu. Ustrój i uposażenie, Poznań 1972.

- Historia Litwy, Wrocław 1967.

W. Przyałgowski, Zywoty biskupów wileńskich, Petersburg 1860. - Relationes status dioecesium in Magno Ducatu Lituaniae. Vol. 1: Dioeceses Vilnensis et Samogitiae. Red. P. Rabikauskas, Romae 1971.

J. S a wi cki, Concilia Poloniae. T. 2: Synody diecezji wileńskiej i ich statuty, Warszawa 1948.

M. Stryjkowski, Kronika polska, litewska, żmudzka i wszystkiej Rusi, Warszawa 1846.

- O poczqtkach, wywodach, dzielnościach, sprawach rycerskich i domowych stawnego narodu litewskiego, żemojdzkiego $i$ ruskiego [...], Warszawa 1978.

G. U th, Szkic historyczno-biograficzny zakonu augustiańskiego w Polsce, Kraków 1930.

M. Wołonczewski, Biskupstwo żmujdzkie, Kraków 1898.

W. Z a horski, Kościót św. Michała i klasztory panien bernardynek $w$ Wilnie, Wilno 1911.

- Pierwsze szpitale wileńskie, „Pamiętnik Wileńskiego Towarzystwa Lekarskiego" 1 (1925) z. 2 s. $65-75$. 


\title{
DIE ROMISCH-KATHOLISCHE KIRCHE IN LITAUEN \\ UM DIE WENDE DES 15. UND 16. JAHRHUNDERTS
}

\author{
Zusammenfassung
}

Im Todesjahr des hl. Kasimirs sind noch hundert Jahre nicht verstrichen, seit Litauen christianisiert zu werden begann (1387). Das Volk des territorial sehr ausgedehnten Großherzogtums Litauen, mit Polen durch reine Union verbunden (zu Krewo 1385), war vorwiegend orthodox. Die ersten zwei Bistümer in Litauen wurden in Wilna (1387) und Mediminkai (1417, Samogitien) errichtet. Anfang des $16 \mathrm{Jh}$. werden schon Litauer zu Bischöfen. In diese Zeit fällt auch die Berufung des ersten Weihbischofs in Litauen, nämlich in der Wilner Diözese (1512). Bis zur Mitte des 16. Jh. fanden fünf Synode in Wilna statt (1520, 1527, 1538, 1542, 1546). Dagegen wird in Samogitien die erste Synode im Jahre 1555 abgehalten.

Das anfangs geringe Pfarreinetz entwickelte sich in diesem Zeitabschnitt langsam aber systematisch. Wenn es um 1450 in Hochlitauen 60 Pfarreien gab, so wuchs ein Jahrhundert später die Anzahl von ihnen bis auf 259 an; diese Angaben für Samogitien lauten entsprechend 17 und 43. Die Pfarreien wurden dort gegründet, wo die litauische Bevölkerung in der Mehrheit war. Unter den Ruthenen war fast nur der Adel katholisch. Die Dekanatsorganisation tritt zuerst in der Wilner Diözese zur Mitte des 16. Jh. auf, dann in Samogitien hundert Jahre später.

Unter den Orden entfalteten vor allem die Franziskaner eine rege Tätigkeit (um 1500 besaßen sie schon zwei Kilöster in Wilna und je eines in Kaunas und Oszmiany). Auch die Bernhandiner besaßen damals vier Klöster (Wilna, Kaunas, Tykocin und Polock). Von den anderen unterhielten ihre Klöster noch die Regularkanoniken (Bistriz, Mediminkai), die Augustaner (Grodno) und die Benediktiner (Troki). In Samogitien gab es in dieser Zeit kein Kloster. Was hingegen die Nonnenorden betrifft, hatten nur die Bernhardinenschwester ihr Kloster in Wilna gegründet (1494). Bis zur Zeit der Heranziehung der Jesuiten war der Einfluß der Orden auf die litauische Bevölkerung relativ gering, insbesondere außerhalb Stadtgebiete.

Der Klerus verbreitete nicht nur den neuen Glauben, sondern wirkte auch auf die Entwicklung der Kultur, des Schul- und Heilwesens und natürlich der Charitativwerke ein. Kurz nach Begiim der Christianisierung Litauens wegen des Wikariatssystems in den neuen Pfarreien, wo polnische Prister eingestellt wurden, um Pfarrer zu vertreten, traten natürlich Sprachprobleme auf. Eine radikale Wendung zum Besserern trat auf diesem Gebiet erst dank der Jesuiten ein. Sie förderten die Ortssprache und gründeten dort Druckereien, um Bücher in litauischer und ruthenischer Sprache herausgeben zu können.

In dem behandelten Zeitabschnitt stieß die Seelsorge in Litauen noch auf große Schwierigkeiten verschiedener Art. Das Christentum war dort noch neu, das Gebiet der einzelnen Pfarreien dehnte sich auf hunderte von Kilometern aus (durchschnittlich $600 \mathrm{qkm}$ in Samogitien, $350 \mathrm{qkm}$ in der Diözese Wilna, $950 \mathrm{qkm}$ oder mehr in ruthenischen Bezirken). Die Annahme des katholischen Glaubens werschuf den Oberschichten Litauens auch weltliche Vorteile, vor allem die Möglichkeit staatlicher Amter und höchster Würden in dem Königreich beider Nationen. Dagegen verharrte die Bevölkerung auf dem Lande, die manchmal weit von dem Pfarreisitz entfernt lebte, noch weithin im Heidentum. Archäologische Ausgrabun- 
gen, 1970 in Samogitien durchgeführt, haben bestätigt, daß dort noch zur Mitte der 17. Jh. heidnische Kulte vorkamen.

Von großem Interesse ist das Problem der Koexistenz von Katholikern und Orthodoxen in Litauen zu dieser Zeit. Dieses Zusammenleben beider Konfessionsgruppen gestaltete sich dort kaum verträglich, obwohl man gleichzeitig zugeben muß, daß die Orthodoxe Kirche große Toleranz genoß. Anfang des 16. Jh. gab es z. B. 14 katholische und 15 orthodoxe Kirchen in Wilna.

Verhältnismäßig rasch, insbesondere nach der Schlacht bei Polock (1918), begann sich der Kult des hl. Kasimirs, im Wilner Dom bestattet, zu verbreiten, wozu das polnische und das litauische Rittertum viel beigetragen hatte. Dieser Kult belebte die Raligiosität der Litauer und verstärkte die dortige Stellung der Kirche.

Gegen Ende der zwanziger Jahre des 16. Jh. drang dort die Reformation ein, insbesondere der Calvinismus und der Arianismus, denen sich ein großer Teil des hohen Adels anschloß. Die erste lutheranische Gemeinde wurde in Zejny (Samogitien) gegründet. Bald danach jedoch kamen die Jesuiten, die im Laufe von hundert Jahren den Protestantismus aus ganz Litauen fast total verdrängten. 